\title{
Mechanical Design of Slug Catcher
}

\author{
Ayende $^{1 *}$, Mohammad Zafrullah Arsyad ${ }^{2}$, Totok Widiyanto ${ }^{3}$ \\ 1,2,3Politeknik Energi dan Mineral [PEM] Akamigas, Jln Gadjah Mada No. 38, Cepu 58315
}

\begin{abstract}
In the upstream oil and gas industry Slug Catcher is a separator to separate heavy liquid hydrocarbons and the gaseous lighter fraction. Slug Catcher is a cylindrical pressure vessel which has a horizontal orientation designed with an internal pressure of $84.37 \mathrm{~kg} / \mathrm{cm}^{2}, 73,89{ }^{\circ} \mathrm{C}$ temperature, $3 \mathrm{~mm}$ corrosion allowance, 3,500 $\mathrm{mm}$ length, and 1,750 $\mathrm{mm}$ diameter. This paper aims to design a Slug Catcher from a mechanical side that is safe and able to withstand the stress caused by internal pressure. General design which includes calculation of thickness of shell, heads, and nozzles, maximum allowable working pressure (MAWP), and minimum design metal temperature (MDMT) using ASME BPVC Section VIII Division 1. Based on the results obtained the nominal shell thickness is $60 \mathrm{~mm}$, head minimum thickness $58 \mathrm{~mm}$, material specification for shell and head is SA $516 \mathrm{Gr} 70$. In general, the selected material uses low carbon steel; flange rating class 600; vessel's Maximum Allowable Working Pressure is $87.60 \mathrm{~kg} / \mathrm{cm}^{2}$; hydrostatic test pressure is $113 \mathrm{~kg} / \mathrm{cm}^{2}$.
\end{abstract}

Keywords : pressure vessel, slug catcher,thickness, circumferential stress, saddle support

ayende2018@gmail.com

\section{Introduction}

Pressure vessel is most common non-rotating equipment in the oil and gas industry. Pressure vessel used to separate fluids into different phases or temporarily store the fluid before it processed to the next stage. Slug Catcher is one of the type of pressure vessel, this equipment used in the upstream oil and gas industry.

The design of a Slug Catcher should consider suitability to the operating conditions, comply to the applicable code \& standard, also take into account the construction design such as dimensions, Maximum Allowable
Working Pressure (MAWP), and material strength. Generally, the standard \& code applies to the design of the construction of pressure vessels is ASME BPVC Section VIII, Division 1.

\section{Materials and Methods}

Design data uses ASME Sect. VIII Div. 1 as code standard. The methodology design of this slug catcher is shown in Figure 1 as follows: 


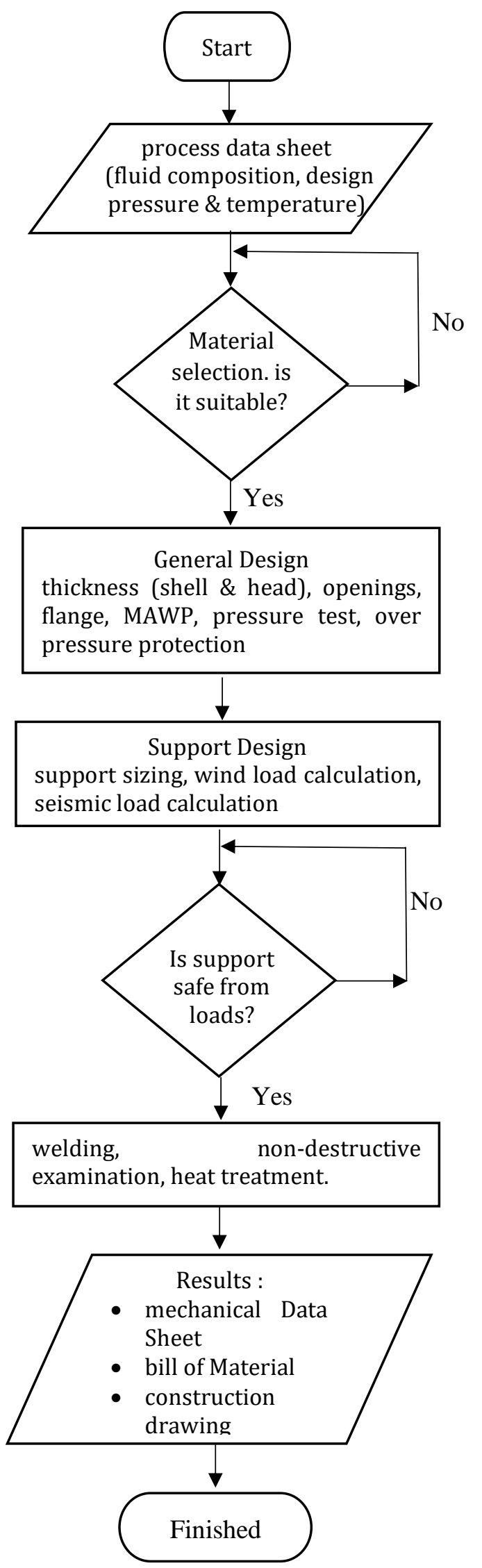

Figure 1. Slug catcher Design flowchart

\section{A. Design Data}

Design data of the pressure vessel show at table 2.1 as follow :

Table 1. Design Data

\begin{tabular}{l|l}
\hline \hline Code Standard & ASME Sect. VIII Div. 1 \\
\hline \hline Orientation & Horizontal \\
\hline Diameter (ID) & $1750 \mathrm{~cm}$ \\
\hline Radius (Ri) & $875 \mathrm{~mm}$ \\
\hline Length (T/T) & $3500 \mathrm{~mm}$ \\
\hline Design Temperature & $73,89^{\circ} \mathrm{C}$ \\
\hline Design Pressure & $84,37 \mathrm{~kg} / \mathrm{cm}^{2}$ \\
\hline Corrosion Allowance & $3 \mathrm{~mm}$ \\
\hline \hline
\end{tabular}

\section{B. Material Selection}

The material selection based on following consideration :

\section{1) Service fluids}

The service fluid to this Slug Catcher is a mixture of natural gas and water, the composition of natural gas show at table 2.2 as follow :

\section{Table 2. Natural Gas Composition}

\begin{tabular}{l|r|r}
\hline Component & $\begin{array}{c}\text { Mole } \\
\text { Fraction } \\
(\%)\end{array}$ & $\begin{array}{c}\text { Concentration } \\
(\mathrm{ppm})\end{array}$ \\
\hline \hline Methane & 0.83 & 8300 \\
\hline Ethane & 0.044 & 440 \\
\hline Propane & 0.036 & 360 \\
\hline i-Butane & 0.01 & 100 \\
\hline n-Butane & 0.011 & 110 \\
\hline i-Pentane & 0.005 & 50 \\
\hline n-Pentane & 0.003 & 30 \\
\hline Hexane+ & 0.005 & 50 \\
\hline Helium & 0.00 & 0 \\
\hline Argon & 0.008 & 80 \\
\hline Oxygen & 0.00 & 0 \\
\hline CO 2 & 0.046 & 460 \\
\hline Nitrogen & 0.002 & 20 \\
\hline $\mathrm{H}_{2} \mathrm{~S}$ & 0.00 & 0 \\
\hline \hline
\end{tabular}

From the natural gas composition above, compared to the API Spec 12J, Specification for Oil and Gas Separator Appendix B, the operating fluid in the Slug Catcher is not a corrosive fluids based on the data below : 
- Oxygen 0 ppm $(<0,0005$ ppm),

- Carbon Dioxide 460 ppm (<600 ppm)

- Hydrogen Sulfide content 0 ppm.

The construction of Slug Catcher does not require corrosion resistant material specifications. Several choices of materials that can be used such as steel (carbon steel, low alloy steel), lead, nickel, inconel, monel, and stainless steel.

\section{2) Design Temperature}

Temperature will have an impact on tensile strength and modulus of elasticity, which of course will affect the allowable stress of the material. For example, mild steel (low carbon steel, carbon $<0.3$ percent) has an allowable stress of $20 \mathrm{ksi}$ at $100{ }^{\circ} \mathrm{F}$, which changes to only $12 \mathrm{ksi}$ at $800^{\circ} \mathrm{F}$. Thus, if an equipment is designed to operate at high temperatures, a material that can withstand its strength must be chosen. The design temperature of the Slug Catcher is $73.89^{\circ} \mathrm{C}$ which is included in the lower service temperature. Since the material chosen is used for intermediate temperature services, it does not require special specifications such as high temperature service or cryogenic service.

\section{3) Fabricability}

The fabricability of materials must be considered according to the capability of shop work, in the end, it is related to the fabrication cost and time. Generally the main fabrication process carried out on vessels includes machining, forming (cold working), and welding.

\section{4) Cost}

Because material costs vary widely, designers must evaluate material costs with other factors such as corrosion, replacement costs, and expected equipment life. Estimated material prices use references from Structural Analysis and Design of Process Equipment, Maan H. Jawad and James R. Farr 3rd per year 2017 [9]. Material choices are suitable for operating fluids in Slug Catcher, then ranked to choose the material with the most cost minimum, and consider the ease of fabrication of each material. Thus, carbon steel is the most suitable material.

Table 3. Rank of Materials

\begin{tabular}{c|c|c|c}
\hline Rank & Material & $\begin{array}{c}\text { Cost } \\
(\$ / \mathrm{lb})\end{array}$ & $\begin{array}{c}\text { Machining } \\
\& \\
\text { Welding }\end{array}$ \\
\hline \hline 1 & Carbon steel & 0,80 & $\mathrm{~S}$ \\
\hline 2 & $\begin{array}{c}\text { Low alloy } \\
\text { steel }\end{array}$ & 1,60 & $\mathrm{~S}$ \\
\hline 3 & $\begin{array}{c}\text { Stainless } \\
\text { steel }\end{array}$ & 2,70 & $\mathrm{~S}$ \\
\hline 4 & Monel & 15,00 & $\mathrm{~S}$ \\
\hline 5 & Inconel & 18,00 & $\mathrm{~S}$ \\
\hline \hline
\end{tabular}

Note : S (Satisfactory) means no special techniques are needed.

\section{5) Material Specification}

Material specifications used for vessel construction must be registered in ASME Section II part D. Generally, the material chosen is materials that commonly used in the industry and easily available in the market to make it easier for future needs such as repair. Material specifications for each part of the vessel can be seen in the following table.

Table 4. Material Specification Used

\begin{tabular}{c|c}
\hline \hline Part & Material Specification \\
\hline \hline Shell & SA-516 gr.70 \\
\hline Head & SA-516 gr.70 \\
\hline Reinforcing Pad & SA-516 gr.70 \\
\hline Nozzle neck & SA-105 (Forging) \\
& SA-516 gr.70 (Plate) \\
& SA-106 gr. B \\
\hline Flange & SA-105 \\
\hline Fittings & SA-234 gr. WPB \\
\hline Bolt/ Nuts & SA 193 B7/ SA 1942H \\
\hline Anchor Bolt & SA-307 B \\
\hline Support Pad & SA-36 \\
\hline \hline
\end{tabular}

\section{6) Mechanical Properties and Chemical Composition of Materials}

The mechanical properties of the material in the form of yield strength ( $\sigma y)$ and tensile strength $(\sigma \mathrm{u})$ in the material can be seen in ASME Sec. II-D (Metric), yield strength and tensile strength determine the maximum allowable stress (S) on a material. 
The chemical composition of a material determines the chemical properties of the material. The chemical composition can be found in ASME Sec. II-A.

The mechanical properties of the material used in this Slug Catcher can be seen in the following table, the maximum allowable stress is determined at the design temperature $\left(73.89^{\circ} \mathrm{C}\right)$.

Table 5. Mechanical Properties of Materials

\begin{tabular}{l|c|c|c}
\hline \hline & \multicolumn{2}{|c|}{ Strength } & $\begin{array}{c}\text { Max. Allow. } \\
\text { Stress }\end{array}$ \\
\cline { 3 - 4 } Material & $\begin{array}{c}\text { Tensile } \\
\left(\mathrm{kg} / \mathrm{cm}^{2}\right)\end{array}$ & $\begin{array}{c}\text { Yield } \\
\left(\mathrm{kg} / \mathrm{cm}^{2}\right)\end{array}$ & $\left(\mathrm{kg} / \mathrm{cm}^{2}\right)$ \\
\hline \hline SA-36 & 4078,88 & 2549,30 & 1162,48 \\
\hline SA-105 & 4945,64 & 2549,30 & 1407,21 \\
\hline $\begin{array}{l}\text { SA-106 } \\
\text { gr.B }\end{array}$ & 4231,84 & 2447,33 & 1203,27 \\
\hline $\begin{array}{l}\text { SA-516 } \\
\text { gr.70 }\end{array}$ & 4945,64 & 2651,27 & 1407,21 \\
\hline $\begin{array}{l}\text { SA-193 } \\
\text { gr. B7 }\end{array}$ & 8106,77 & 6679,17 & 1621,35 \\
\hline $\begin{array}{l}\text { SA-307 } \\
\text { gr. B }\end{array}$ & 4231,84 & 2549,30 & 492,52 \\
\hline $\begin{array}{l}\text { SA-234 } \\
\text { WPB }\end{array}$ & 4231,84 & 2447,33 & 1498,99 \\
\hline \hline
\end{tabular}

\section{General Design}

The general design of the Slug Catcher includes:

\section{1) Thickness Calculation}

There are several types of wall thickness that are calculated in the design of this pressure vessel, including Required thickness, which is the minimum thickness needed to withstand internal or external pressure on the vessel before the corrosion allowance is added, Design thickness is the amount of required thickness plus the corrosion allowance (UG25), Nominal thickness, the thickness of the plate ordered, must not be thinner than the design thickness. The thickness is selected based on market availability.

\section{a. Shell}

Calculated with UG-27, the effect of the greatest stress, namely the circumferential stress uses the formula as below:

$$
t=\frac{P R}{S E-0,6 P}
$$

\section{b. Head}

Calculated with UG-32, the type of head used is ellipsoidal so it uses the formula as below :

$$
t=\frac{P D}{2 S E-0,2 P}
$$

\section{c. Nozzle}

The nozzle neck thickness is calculated by the UG-45. For access openings and openings used for inspection only

$$
t_{U G-45}=t_{a}
$$

For other nozzles :

$$
\begin{aligned}
& t_{b}=\min \left[t_{b 1}, \max \left(t_{b 1}, t_{b 2}\right)\right] . \\
& t_{U G-45}=\max \left(t_{a}, t_{b}\right) \ldots \ldots \ldots \ldots \ldots \ldots
\end{aligned}
$$

\begin{tabular}{|c|c|c|}
\hline \multirow[t]{2}{*}{ Nominal Size } & \multicolumn{2}{|c|}{$\begin{array}{c}\text { Minimum Wall } \\
\text { Thickness }\end{array}$} \\
\hline & in. & $\mathrm{mm}$ \\
\hline NPS $1 / 8$ (DN 6) & 0.060 & 1.51 \\
\hline NPS 1/4 (DN 8) & 0.077 & 1.96 \\
\hline NPS 3/8 (DN 10) & 0.080 & 2.02 \\
\hline NPS $1 / 2$ (DN 15) & 0.095 & 2.42 \\
\hline NPS 3/4 (DN 20) & 0.099 & 2.51 \\
\hline NPS 1 (DN 25) & 0.116 & 2.96 \\
\hline NPS 11/4 (DN 32) & 0.123 & 3.12 \\
\hline NPS $11 / 2$ (DN 40) & 0.127 & 3.22 \\
\hline NPS 2 (DN 50) & 0.135 & 3.42 \\
\hline NPS 21/2 (DN 65) & 0.178 & 4.52 \\
\hline NPS 3 (DN 80) & 0.189 & 4.80 \\
\hline NPS 31/2 (DN 90) & 0.198 & 5.02 \\
\hline NPS 4 (DN 100) & 0.207 & 5.27 \\
\hline NPS 5 (DN 125) & 0.226 & 5.73 \\
\hline NPS 6 (DN 150) & 0.245 & 6.22 \\
\hline NPS 8 (DN 200) & 0.282 & 7.16 \\
\hline NPS 10 (DN 250) & 0.319 & 8.11 \\
\hline$\geq$ NPS 12 (DN 300) & 0.328 & 8.34 \\
\hline
\end{tabular}

Table 6. Nozzle Min. Thickness Req. 
The nozzle requirement data from the client data sheet proposal are:

Table 7. Nozzle Required

\begin{tabular}{c|c|c|c|c}
\hline \hline Nozzle & $\begin{array}{c}\text { Size } \\
\text { (In) }\end{array}$ & Rating & $\begin{array}{c}\text { Face \& } \\
\text { Type }\end{array}$ & Service \\
\hline \hline N1 & 16 & $600 \#$ & RFV3 & Inlet \\
\hline N2 & 16 & $600 \#$ & RFV3 & Outlet \\
\hline N3 & 2 & $600 \#$ & RFWN & Drain \\
\hline N4 & 4 & $600 \#$ & RFWN & Drain \\
\hline N5 & 2 & $600 \#$ & RFWN & PSV \\
\hline K1 & 2 & $600 \#$ & RFWN & PT \\
\hline K2 & 2 & $600 \#$ & RFWN & PG \\
\hline K3 & 2 & $600 \#$ & RFWN & TT \\
\hline K4 & 2 & $600 \#$ & RFWN & TG \\
\hline K5A/K5B & 2 & $600 \#$ & RFWN & $\begin{array}{c}\text { Briddle } \\
\text { (LG/LT) }\end{array}$ \\
\hline K6A/K6B & 2 & $600 \#$ & RFWN & $\begin{array}{c}\text { Chamber } \\
\text { LT }\end{array}$ \\
\hline MH & 20 & $600 \#$ & RFV3 & $\begin{array}{c}\text { Manway } \\
\text { Blind } \\
\text { Flange }\end{array}$ \\
\hline \hline
\end{tabular}

For RFWN nozzles, it can use a flange (ASME B16.5) connected to a pipe (ASME B36.10), while RFV3 uses an integral nozzle (forging nozzle catalog). The results of the thickness calculation are in the following table :

Table 8. Nozzle Thickness Calculation Results

\begin{tabular}{c|c|c|c}
\hline Thickness & $\begin{array}{c}\text { Required, } \mathrm{t}_{\mathrm{r}} \\
(\mathrm{mm})\end{array}$ & $\begin{array}{c}\text { Design, } \\
\mathrm{t}_{\min }(\mathrm{mm})\end{array}$ & $\begin{array}{c}\text { Nominal, } \\
\mathrm{t}_{\mathrm{n}}(\mathrm{mm})\end{array}$ \\
\hline Shell & 54,42 & 57,42 & 60 \\
\hline Head & 52,77 & 55,77 & 58 \\
\hline $\begin{array}{c}\text { Nozzle N1\& } \\
\text { N2 }\end{array}$ & 15,64 & 15,64 & 68,33 \\
\hline $\begin{array}{c}\text { Nozzle N2, } \\
\text { N3, N5, K1, } \\
\text { K2, K3, K4, } \\
\text { K5A/B, } \\
\text { K6A/B }\end{array}$ & 15,64 & 15,64 & 68,33 \\
\hline $\begin{array}{c}\text { Nozzle N4 } \\
\text { Nozzle MH }\end{array}$ & 8,27 & 11,27 & 14,98 \\
\hline \hline
\end{tabular}

\section{2) Reinforcement}

The basis of the code reinforcement rule ensures that at any section crossing through an opening, the area of the shell lost due to the opening is replaced by a material which has sufficient strength and an area equivalent to that of the opening. Paragraph UG-36 (c) (3) provides exemption from the need of reinforcement if the opening is not greater than $3 \frac{1}{2}$ in. $(89 \mathrm{~mm})$ diameter - in a shell or vessel head having a minimum thickness of $3 / 8 \mathrm{in}(10 \mathrm{~mm})$ or less, or $23 / 8 \mathrm{in} .(60 \mathrm{~mm})$ diameter - on a shell or vessel head that has a minimum thickness of more than $3 / 8$ in. (10 $\mathrm{mm})$. The calculation of reinforcement requirements is given in Figure UG-37.1 (Figure 2). If the available area is greater than or equal to the required area, the use of reinforcement is not necessary.

However, if the available area is less than the required area, it can be done in several ways, such as increasing the nozzle neck wall thickness (increasing pipe schedule), using a reinforcing pad, or using a forging nozzle (integral flange). Of the several options, considerations were made to choose the most effective method in terms of cost, difficulty level and processing time.
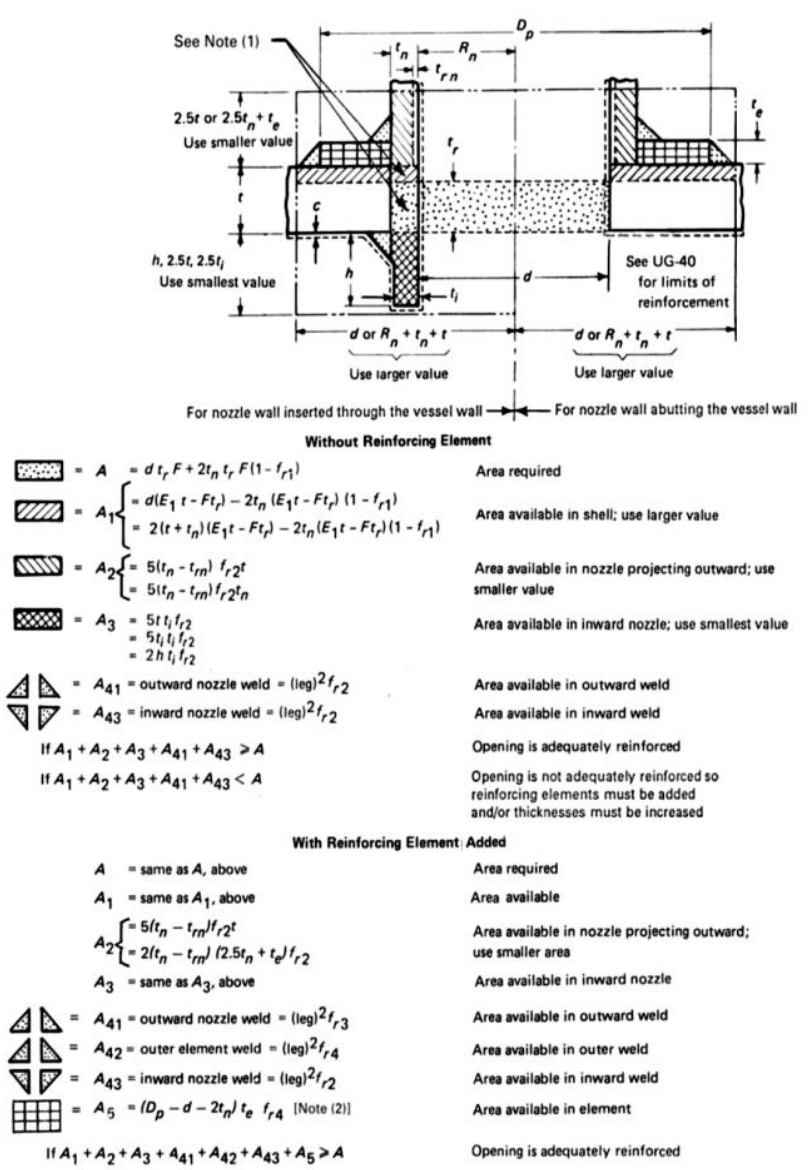

Figure 2. Nomenclature and reinforced opening formula 
Table 9. Reinforcement Requirements Calculation Result

\begin{tabular}{c|c|c|c}
\hline \multirow{2}{*}{ Aavail. } & \multirow{2}{*}{ Areq. } & \multicolumn{2}{|c}{ Pad } \\
\cline { 3 - 4 } & & width & $t_{\text {pad }}$ \\
\hline $\mathrm{cm}^{2}$ & \multicolumn{2}{|c}{$\mathrm{mm}$} \\
\hline 309,46 & 224,43 & $\mathrm{~N} / \mathrm{A}$ & $\mathrm{N} / \mathrm{A}$ \\
\hline 309,46 & 224,43 & $\mathrm{~N} / \mathrm{A}$ & $\mathrm{N} / \mathrm{A}$ \\
\hline exempted & N/A & N/A \\
\hline 92,69 & 55,59 & 200 & 60 \\
\hline exempted & N/A & N/A \\
\hline exempted & N/A & N/A \\
\hline exempted & N/A & N/A \\
\hline exempted & N/A & N/A \\
\hline exempted & N/A & N/A \\
\hline exempted & N/A & N/A \\
\hline exempted & N/A & N/A \\
\hline exempted & N/A & N/A \\
\hline exempted & N/A & N/A \\
\hline 366,77 & 279,72 & N/A & N/A \\
\hline \hline
\end{tabular}

\section{3) MAWP}

The Maximum Allowable Working Pressure (MAWP) is the maximum pressure allowed in the normal operating position at a certain temperature under "hot and corroded" conditions, usually the design temperature (UG-98). Each vessel element has a different MAWP, the lowest MAWP of all the elements is chosen as the MAWP of the vessel.

\section{Shell}

$$
P_{w}=\frac{S_{D T} E t_{s c}}{R c+0,6 t_{s c}}
$$

\section{Ellipsoidal Head}

$$
P_{w}=\frac{2 S_{D T} E t_{h c}}{D c+0,2 t_{h c}}
$$

From the calculation, the lowest MAWP is at the ellipsoidal head with $87.60 \mathrm{~kg} / \mathrm{cm}^{2}$.

\section{4) Test Pressure}

A requirement to determine the test pressure based on calculations, carried out to find out if there is a leak in the vessel:

Hydrostatic Test UG-99(c)

$$
P_{\text {hydro }}=1,3 M A W P \times \frac{S_{\text {test temp. }}}{S_{\text {design temp. }}}(8)
$$

The pressure obtained for the hydrostatic test is $113 \mathrm{~kg} / \mathrm{cm}^{2}$, if the hydrostatic test is not possible to perform, then a pneumatic test can be a substitute for testing vessels with the formula

$$
P_{\text {pneu }}=1,1 M A W P \times \frac{S_{\text {test temp. }}}{S_{\text {design temp. }}}(9)
$$

then the pressure for the pneumatic test $=$ $96.36 \mathrm{~kg} / \mathrm{cm}^{2}$.

\section{5) Overpressure Protection}

All pressure vessels must be equipped with overpressure protection. If a pressure relief device is used, the pressure inside the vessel should not be more than $10 \%$ or 3 psi $(20$ $\mathrm{kPa}$ ) of the MAWP (whichever is greater). Meanwhile, if a dual (more than one) pressure relief device is used, the pressure in the vessel should not be more than $16 \%$ or 4 psi (30 $\mathrm{kPa}$ ) of MAWP (UG-125) (c). The pressure tolerance, more or less, of the pressure relief valve should not be more than $2 \mathrm{psi}(15 \mathrm{kPa})$ for pressures less than or equal to 70 psi (50 $\mathrm{kPa}$ ) and $3 \%$ for pressures above 70 psi (500 $\mathrm{kPa}$ ).

From the results of the above calculations, it can be seen that the PSV set pressure on the Slug Catcher is $96.36 \mathrm{~kg} / \mathrm{cm}^{2}$ with an over / under pressure tolerance of $2.63 \mathrm{~kg} / \mathrm{cm}^{2}$.

\section{Loads Calculation}

loads that generally need to be considered on the vessel are:

\section{1) Pressure Load}

Derived from internal or external pressure, in this case the largest Slug Catcher pressure load during the hydrostatic test.

\section{2) Moment Load}

Due to wind, earthquake, erection, or transportation, in this case the load by wind and earthquake is calculated using the ASCE 7-16 standard, a design wind force of 61.26 kgf is obtained and a design seismic force is 474.4 kgf. 


\section{3) Weight Load}

The type of weight calculated is the empty weight (the total weight of the vessel sitting on the foundation), the operating weight (the empty weight plus the weight of the operating fluid) and the test weight (the vessel full of water). The weight of a component can be calculated by the surface area times the thickness times the density. For the specific gravity of carbon steel (carbon steel) which is generally used in vessels $7.85 \mathrm{~g} / \mathrm{cm}^{3}$ or 0.284 $\mathrm{lb} / \mathrm{in}^{3}$. A practical calculation formula for determining the weight of a vessel made from carbon steel can be seen in the following table.

Table 10. Vessel Weight Formula

\begin{tabular}{l|l}
\hline \hline Identification & Formula \\
\hline Shell & $\pi \mathrm{Dm} \mathrm{Lt} \rho$ \\
\hline Spherical Head & $\pi \mathrm{Dm}^{2} \mathrm{t} \rho$ \\
\hline Hemispherical Head & $1,57 \mathrm{Dm}^{2} \mathrm{t} \rho$ \\
\hline $2: 1$ Ellipsoidal Head & $1,084 \mathrm{Dm}^{2} \mathrm{t} \rho$ \\
\hline Cone & Act $\rho$ \\
\hline \hline
\end{tabular}

After the weight of all components has been added to the total weight, a typical percentage is added to allocate the weight of the other components and the weight of the weld.

Table 11. Typical Percentage of Weight

\begin{tabular}{c|c}
\hline Total Weight & Added by \\
\hline \hline$<50.000 \mathrm{lb}$ & $10 \%$ \\
\hline $50.000-75.000 \mathrm{lb}$ & $8 \%$ \\
\hline $75.000-100.000 \mathrm{lb}$ & $6 \%$ \\
\hline$>100.000 \mathrm{lb}$ & $5 \%$ \\
\hline \hline
\end{tabular}

For vessel components: Flange-Flange weight see ASME B16.5 Pipe Flanges and Flanged Fittings or in the product catalog. Pipe - Pipe weights can be found in ASME B36.10. Manway - Manway weight can be seen in ASME 16.47. There are two types of fluid weight calculated, the weight of the operating fluid and the weight of the test fluid. This weight can be calculated by multiplying the volume of a component by the density.
The formula for calculating the volume of each vessel component can be seen in the following.

Table 12. Vessel Volume Formula

\begin{tabular}{l|l}
\hline \hline Section & Volume \\
\hline \hline Cylinder & $\pi \mathrm{D}^{2} \mathrm{~h} / 4$ \\
\hline Sphere & $\pi \mathrm{D}^{3} / 6$ \\
\hline Ellipsoidal Head & $\pi \mathrm{D}^{2} \mathrm{~h} / 6$ \\
\hline 2:1 S.E. Head & $\pi \mathrm{D}^{3} / 24$ \\
\hline Ellipsoidal Head & $\pi \mathrm{D}^{2} \mathrm{~h} / 6$ \\
\hline F\&D Head & $\pi \mathrm{D}^{3} \mathrm{~K} / 12$ \\
\hline Cone & $\pi \mathrm{D}^{2} \mathrm{~h} / 12$ \\
\hline \begin{tabular}{l} 
Hemispherical Head \\
\hline \hline
\end{tabular}
\end{tabular}

The results of weight calculations are in the following table.

Table 13. Slug Catcher Weight

\begin{tabular}{l|l}
\hline \multicolumn{2}{c}{ Vessel Total } \\
\hline \hline Operating weight & $17376 \mathrm{~kg}$ \\
\hdashline Empty weight & $16872 \mathrm{~kg}$ \\
\hline Test weight & $26667 \mathrm{~kg}$ \\
\hline Capacity & $9824 \mathrm{liter}$ \\
\hline
\end{tabular}

\section{E. Design of Vessel Support}

This slug catcher has a horizontal orientation so that it uses a support saddle type, the design method uses analysis by L.P. Zick. The distance between the head tangent line and saddle must not be more than 0.2 times the length of the vessel. The minimum contact angle suggested by the ASME Code is $120^{\circ}$, except for a very small vessels.

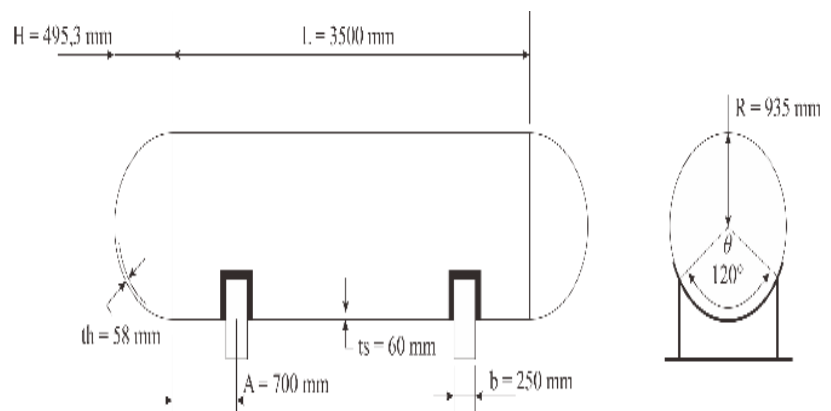

Figure 3. Design Saddle Dimension 
Total force reaction at saddle : $\mathrm{Q}=$ terbesar $\begin{array}{lllll}\text { diantara } & \mathrm{Q}_{1} & \text { (Longitudinal) dan } & \mathrm{Q}_{2}\end{array}$ (transversal).

$$
\begin{aligned}
& Q_{1}=\frac{W_{o}}{2}+\frac{F_{L} B}{L_{S}} \ldots \\
& Q_{2}=\frac{W_{o}}{2}+\frac{3 F_{T} B}{E}
\end{aligned}
$$

the calculation results show that the largest total reaction force received by the vessel is based on the transverse seismic load of $10421.5 \mathrm{kgf}$.

Stress due to internal pressure :

$$
\sigma x=\frac{P R}{2 t_{s}} .
$$

Obtained $\sigma_{\mathrm{x}}=657,97 \mathrm{~kg} / \mathrm{cm}^{2}$

Vessels using a saddle experience:

1) Longitudinal bending stress

At saddle

$$
S_{1}= \pm \frac{Q A\left(1-\frac{1-\frac{A}{L}+\frac{R^{2}-H^{2}}{2 A L}}{1+\frac{4 H}{3 L}}\right)}{K_{1} R^{2} t s}
$$

Between two saddles (midspan)

$$
S_{1}= \pm \frac{\frac{Q L}{4}\left(\frac{1+2 \frac{R^{2}-H^{2}}{L^{2}}}{1+\frac{4 H}{3 L}}-\frac{4 A}{L}\right)}{\pi R^{2} t s}
$$

Where $\mathrm{K} 1=0.335$, the largest longitudinal stress (S1) is found in the saddle, which is 7.6 $\mathrm{kg} / \mathrm{cm}^{2}$. Maximum allowable stress: Tension: $\mathrm{S} 1+\sigma \mathrm{x} \leq \mathrm{SE}=665.57 \mathrm{~kg} / \mathrm{cm}^{2} \leq 1406 \mathrm{~kg} / \mathrm{cm}^{2}$, the tension stress is acceptable; Compressive: $\mathrm{t} / \mathrm{R} \geq 0.005=0.0641 \geq 0.005$ so that compressive stress is not considered.

\section{2) Tangential shear stress}

Because A> R / 2 (700 mm> 467.5 $\mathrm{mm}$ ), the following equation is used.

$$
S_{2}=\frac{K_{2} Q}{R t s}\left(\frac{L-2 A}{L+\frac{4}{3} H}\right)
$$

Where $\mathrm{K} 2=1.171$, obtained S2 $=10.99$ $\mathrm{kg} / \mathrm{cm}^{2}$. Max. allowable stress: $\mathrm{S} 2 \leq 0.8 \mathrm{Ss}=$ $10.99 \mathrm{~kg} / \mathrm{cm}^{2} \leq 929.98 \mathrm{~kg} / \mathrm{cm}^{2}$, tangential shear stress is acceptable.

\section{3) Circumferential stress}

Because $\mathrm{L} \geq 8 \mathrm{R}$ (3500 $\mathrm{mm} \geq 7480 \mathrm{~mm}$ ), used the following equation.

$$
S_{4}=\frac{Q}{4 t s(b+1,56 \sqrt{R t s})}-\frac{12 K_{6} Q R}{L t s^{2}} .
$$

Where $\mathrm{K} 6=0.03$, obtained $\mathrm{S} 4=-35.12$ $\mathrm{kg} / \mathrm{cm}^{2}$. Max. allowable stress: $\mathrm{S} 4 \leq 1.5 \times \mathrm{Ss}=$ $-35.12 \mathrm{~kg} / \mathrm{cm}^{2} \leq 1743.72 \mathrm{~kg} / \mathrm{cm}^{2}$, the circumferential stress is acceptable.

\section{F. Lifting Lug}

The design of the lifting lug dimensions is based on the calculation of the Slug Catcher weight in erected conditions, namely using an empty weight. The design of the lifting lug dimensions based on the vessel weight can use the image below.

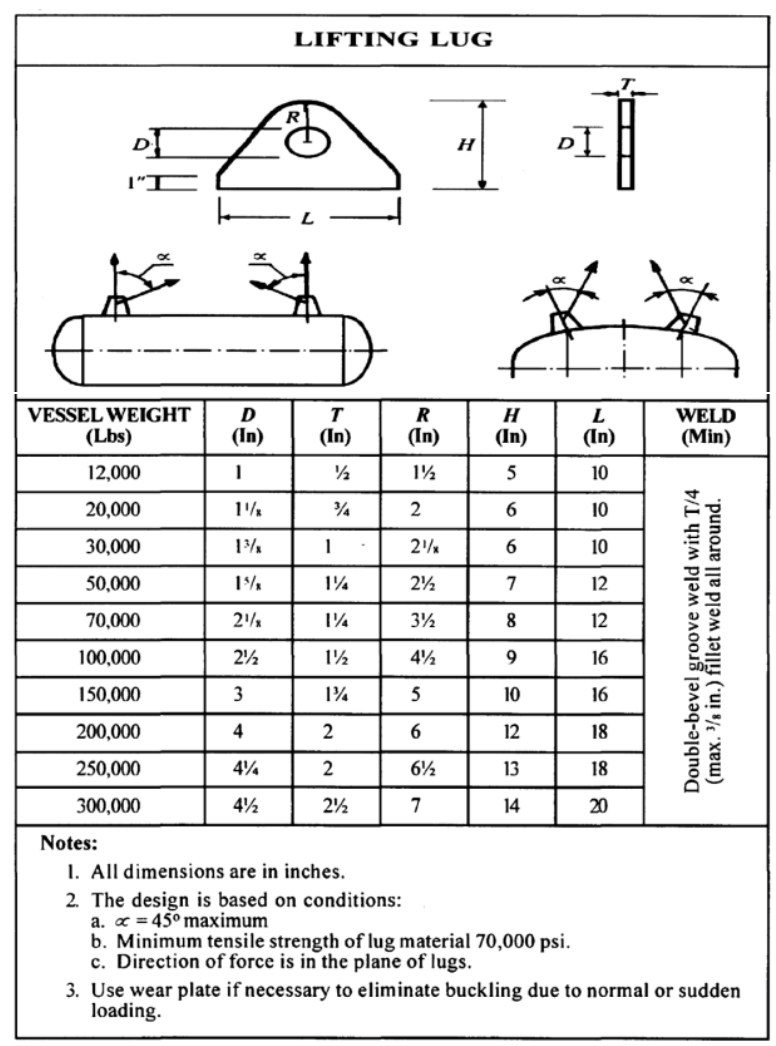

Figure 4. Lifting Lug Dimension 
A vessel weight of $50,000 \mathrm{lb}$ was chosen so that the dimensions are $\mathrm{D}=15 / 8 \mathrm{in} .=41.28$ $\mathrm{mm}, \mathrm{T}=11 / 4$ in. $=31.75 \mathrm{~mm}, \mathrm{R}=21 / 2 \mathrm{in} .=$ $63.5 \mathrm{~mm}, \mathrm{H}=7$ in. $=177.8 \mathrm{~mm}, \mathrm{~W}=12$ in. $=$ $304.8 \mathrm{~mm}$, Fillet weld $=3 / 8 \mathrm{in}=9.5 \mathrm{~mm} \approx 10$ $\mathrm{mm}$.

\section{G. Welding}

The type of welding process used is Shielded Metal Arc Welding (SMAW). The parts of the vessel that will be weld are:

\section{1) Shell}

Shell, which is composed of three steel plates, is welded with a double v-groove type joint. In the following picture. Reviewed from the UW3 , it is included in the joint category A in the form of a longitudinal joint in the shell and joint category $B$ in the form of $a$ circumferential joint in the shell that connects between the steel plates making up the shell.

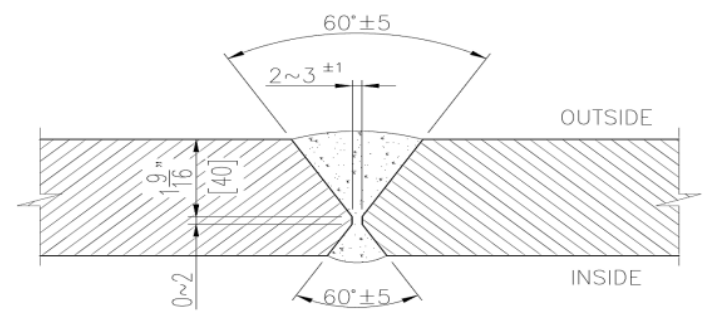

Figure 5. Joint at Shell

\section{2) Head}

The head is welded in the form of a circumferential joint to the shell, which is included in the joint category A, per UW-3, a double v-groove type joint.

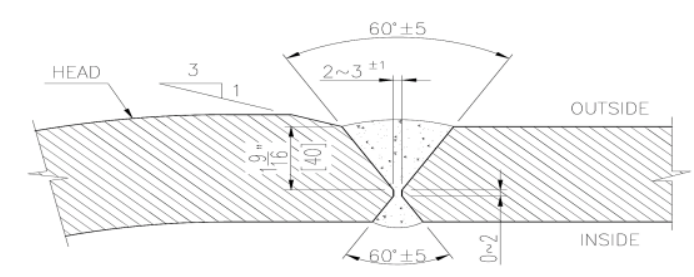

Figure 6. Joint at Head

\section{3) Nozzle}

Welding performed to connect the nozzle to the shell is included in category $D$ joints, per UW-3. Double v-groove joint type.
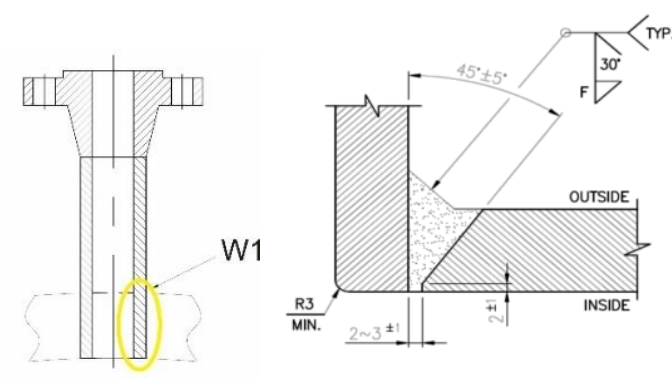

Figure 7. Welding of Nozzle to Shell

\section{4) Neck to Flange}

The welds performed to connect the nozzle neck to the flange are included in category B joints, per UW-3.

\section{5) Saddle Support}

Joint type on saddle support uses fillet weld.

\section{6) Reinforcement Pad}

The type of joint in the reinforcement pad uses fillet weld.

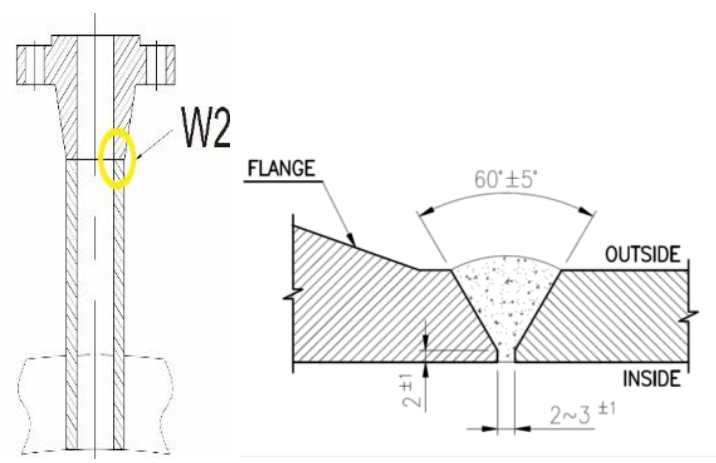

Figure 8. Welding of Neck to Flange

\section{H. Examination}

The type of examination performed in this Slug Catcher is Full Radiography Examination in terms of UW-11 (2), which is intended to determine the quality of the welds that have been carried out at full length on all butt joints in the shell and head of vessels that have a nominal thickness in the weld joints of more than 38. $\mathrm{mm}$. 


\section{Heat Treatment}

Postweld heat treatment (PWHT) performed to heating a vessel at a certain temperature which is intended to release residual stress resulting from mechanical treatment and welding. Based on the thickness calculations that have been done, it is known that the nominal thickness on the shell is $60 \mathrm{~mm}$ and the nominal thickness on the head is $58 \mathrm{~mm}$, thus this Slug Catcher requires PWHT per UW-11 (a) (2) which states that all butt welds are shells and head vessels with a nominal thickness greater than $1 \frac{1}{2}$ in. (38 mm) must be performed PWHT. The WPS used in welding at Slug Catcher includes PWHT, so that the holding temperature and holding time based on WPS is $595^{\circ} \mathrm{C}$ for 2 hours 24 minutes.

\section{J. Low Temperature Operation}

It is the lowest temperature that can operate in a vessel, it is known that the operating temperature of the fluid in this Slug Catcher is $20.34^{\circ} \mathrm{C}$. This is related to the Minimum Design Metal Temperature (MDMT), which is the lowest temperature allowed in a metal material whether it requires a charpy impact test or not. The MDMT set on the vessel is related to the MAWP set on the vessel (UG-20 (b)). It has been previously known that the MAWP vessel is $87.60 \mathrm{~kg} / \mathrm{cm} 2$ which is located on the head, so that MDMT based on the head data can be calculated as follows: Governing thickness $=\mathrm{tn}=58 \mathrm{~mm}$, Curve $=$ For SA-516 plates with a thickness of more than $40 \mathrm{~mm}$, done normalizing. (ASME Sec. IIA). So for SA-516 gr. 70 with a governing thickness of $60 \mathrm{~mm}$ using a D curve, MDMT vessel $=20.34{ }^{\circ} \mathrm{C}$ in terms of UCS-66 using the impact test exemption curve, the combined line of MDMT temperature and governing thickness is above the D curve so that it is free from impact tests, per UCS- 66 (a).

\section{K. Bill of Materials}

A bill of materials (BOM) is a list of raw materials and components with the respective quantities required to manufacture the final product. BOM can be used for communication between the designer and the production.
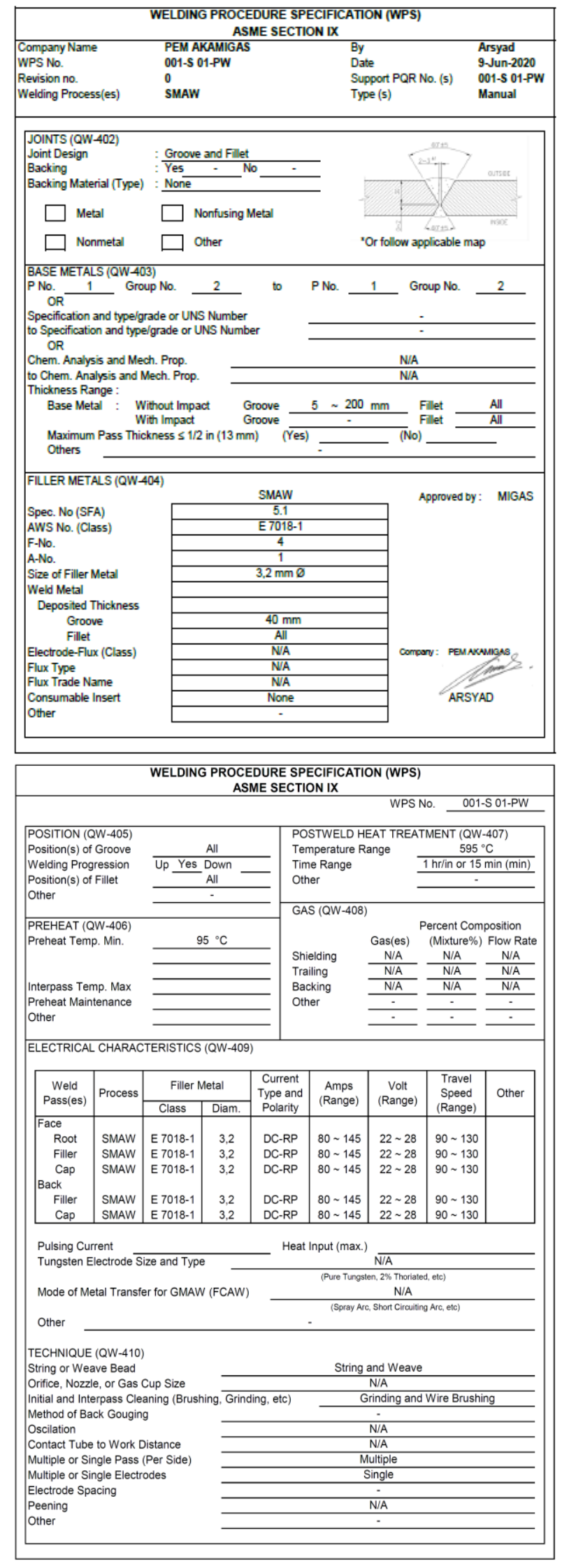

Figure 9. Welding Procedure Specification (WPS) 


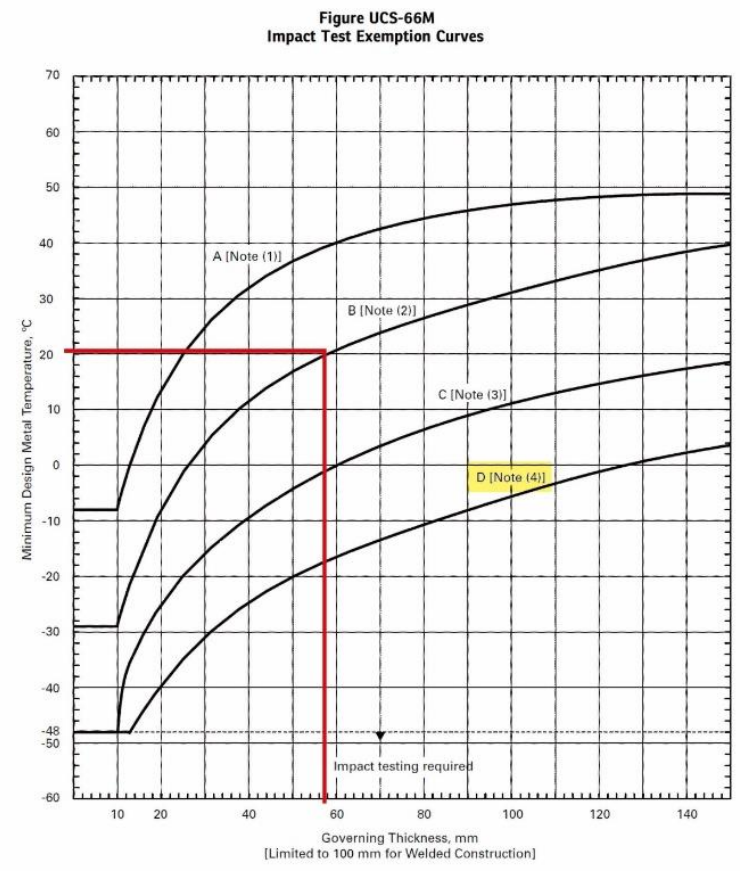

Figure 10. Impact Test Exemption Curve

\section{Construction Drawings}

The main purpose of construction drawings is to provide a graphical representation of what to build. Construction drawing in this Slug Catcher design shows the composition of components, construction details, dimensions, weld joints, material specifications, and bill of materials. The construction drawing of the Slug Catcher design is given in the appendix.

\section{Conclusion}

The main mechanical data on the Slug Catcher are : material shell \& head SA 516 Gr 70: low carbon steel; inside diameter: $1750 \mathrm{~mm}$; vessel thickness: $60 \mathrm{~mm}$; maximum allowable working pressure (MAWP): $87.60 \mathrm{~kg} / \mathrm{cm}^{2}$; hydrostatic test pressure: $1619.34 \mathrm{~kg} / \mathrm{cm}^{2}$; minimum design metal temperature (MDMT): $20.34{ }^{\circ} \mathrm{C}$; Postweld Heat Treatment (PWHT) : Yes; Radiography Examination: RT1; Impact test: exempt per UCS-66.1; Joint efficiency: 1; Corrosion allowance: $3 \mathrm{~mm}$; Support type: Saddle. Based on the design calculation result the Slug Catcher comply to requirement of ASME BPVC Section VIII Division 1.

\section{References}

[1] American Society of Civil Engineers. ASCE/SEI-7 Minimum design loads and associated criteria for buildings and other structures. Virginia: 2016.

[2] American Society of Mechanical Engineers. ASME BPVC Section II Part A Ferrous Material Specifications. New York: 2019.

[3] American Society of Mechanical Engineers. ASME BPVC Section II Part D Properties (Metric). New York: 2019.

[4] American Society of Mechanical Engineers. ASME BPVC Section IX Welding, Brazing, and Fusing Qualifications. New York: 2019.

[5] American Society of Mechanical Engineers. ASME BPVC Section $V$ Nondestructive Examination. New York: 2019.

[6] American Society of Mechanical Engineers. ASME BPVC Section VIII Div1 Rules for Construction of Pressure Vessels. New York: 2019.

[7] American Welding Society. (2001). Welding Handbook. Denvers: 2001.

[8] Ashby, M. F. Materials Selection in Mechanical Design 3rd edition. Burlington: Elsevier Inc. 2005.Bohnart, E. R. Welding : principles and practices. New York: McGraw-Hill. 2017

[9] Jawad, M. H. Structural Analysis and Design of Process Equipment. Hoboken: JohnWiley \& Sons, Inc. 2019

[10] Megyesy, E. F. Pressure Vessel Handbook 12th edition. Oklahoma: Pressure Vessel Publishing, Inc. 1973.

[11] Moss, D. R. Pressure Vessel Design Manual 4th. Waltham: Elsevier Inc. 2013.

[12] Peters, M. S., \& Timmerhaus, K. D. Plant Design and Economics for Chemical Engineers (4th ed.). McGraw-Hill Chemical Engineering Series. 1991.

[13] Towler, G., \& Sinnot, R. Chemical Engineering : Principles, Practice, and Economics of Plant and Process Design. Burlington: Elsevier. 2008. 
LAMPIRAN A. Gambar Teknis Slug Catcher

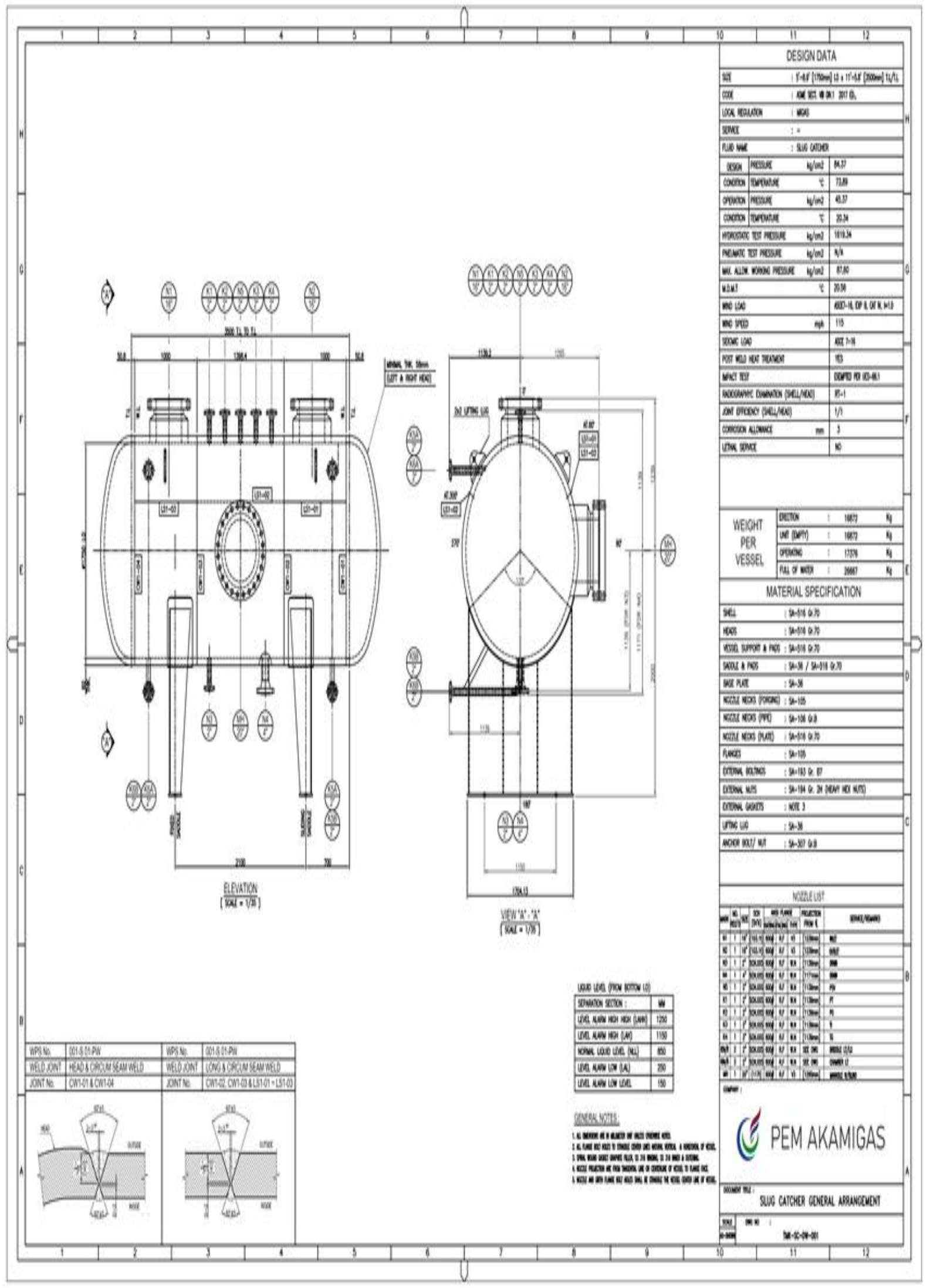

